\title{
La compulsión por recordar, culparse, y exculparse en El lector
}

\author{
Federico Escobar Córdoba
}

\begin{abstract}
The book that projects Bernhard Schlink's fame as a novelist is analyzed in this article which studies its plot and demonstrates the importance of two ideas. The first is that memory, which so influences the present, is scarcely reliable. The second, most importantly, is the idea of guilt linked to the complex and age-old problem of establishing whether it is reasonable to admit that guilt is transmitted from generation to generation. Both ideas are fundamental in all of Schlink's literary works.
\end{abstract}

El lector ha sido un éxito editorial de tal magnitud que quien se acerque al texto probablemente lo hará por recomendación de otro, y tal vez lo hará dotado de alguna idea sobre el contenido de la obra. No obstante, quien tome la versión en español por primera vez notará en la portada una imagen en sepia de una mujer desnuda, y, en primer plano, un libro abierto sobre el cual se impone un objeto con una pequeña suástica dorada. Esta intimación causará cierta perplejidad en los lectores, pues la suástica sólo adquiere sentido casi en la mitad de la novela. Otras ediciones no causan el mismo impacto: la portada estándar de la traducción al inglés ${ }^{1}$ muestra un pequeño ramo de flores reposando sobre un libro abierto; el original en alemán ${ }^{2}$ muestra un atropellado cuadro, del estilo de Edvard Munch, retratando una esquina en la que confluyen varios vehículos y transeúntes anónimos.

\footnotetext{
${ }^{1}$ Bernhard Schlink, The Reader. Tr. Carol Brown Janeway. New York: Vintage (1998).

${ }^{2}$ Bernhard Schlink, Der Vorleser. Zurich: Diogenes Verlag (1995).
} 
La inclusión de la suástica es, de hecho, algo injusta con el desarrollo del libro, proyectando una sombra no invocada. La novela empieza con el inocente recuento de un niño que a los quince años tuvo que recluirse durante meses a causa de hepatitis. La primera manifestación de la enfermedad lo sorprende en la calle, haciéndolo estallar en vómito. Una señora lo ayuda a recomponerse y a limpiar la calle, y lo acompaña a su casa. Al mejorarse de la enfermedad, Michael Berg visita a la señora, Hanna Schmitz, para agradecerle. Durante esta conversación, Hanna entra a un cuarto a cambiarse, y la arquitectura de la escena permite que Michael la observe mientras ella se pone las medias; Hanna lo descubre, y él desaparece corriendo. A la semana, Michael vuelve a la casa de Hanna, y en esa ocasión empieza un romance que durará varios meses. Los episodios diarios de la relación evolucionan hasta incluir un tiempo en el que Michael le lee a Hanna, en voz alta. Ella muestra mucho interés, y se involucra con la trama y los personajes. Michael se entusiasma también, y las sesiones de lectura continúan a lo largo de la relación. El noviazgo se torna torpe en la medida en que Michael se afianza como adolescente, pero no se extingue por ninguna razón distinta a que un día Hanna súbitamente desaparece.

Michael queda marcado por su contacto con Hanna, y adquiere una serie de actitudes y deseos que lo hará poco menos que desagradable. En sus parejas, por ejemplo, siempre desprecia el hecho de no encontrar a Hanna, y en su trato con la gente pretende imponer un aire de superioridad y distancia. Michael decide estudiar derecho, y forma parte de un grupo de estudiantes que busca hacer una revisión del pasado mediante el escrutinio de los procesos adelantados contra agentes del nacional-socialismo. Asistiendo a una audiencia, Michael descubre que una de las acusadas es Hanna; la acusación: haber causado la muerte de docenas de mujeres que, durante las marchas del final de la guerra, fueron incineradas en una iglesia impactada por una bomba. Michael se presenta a todas las audiencias.

Así emerge en la trama de la novela la suástica que la edición en español retrata en la portada. El hecho de haber retenido la incidencia del nazismo hasta la mitad del desarrollo de la obra es esencial para el efecto dramático de la novela, y se asocia con dos ideas que, según la presentación breve que hago en este escrito, son fundamentales no sólo en El lector sino en toda la prosa de Bernhard Schlink.

\section{La memoria}

Iniciemos con la idea de la memoria. Es evidente que, al escribir la novela, Michael ya conocía la acusación que terminaría aprisionando a Hanna. Sin embargo, 
Michael intenta reconstruir su experiencia en una forma semejante a la que él mismo experimentó. Esto lo lleva a imprecisiones y confusiones, de algunas de las cuales él mismo nos alerta. Por ejemplo, el recuerdo que guarda de su primer encuentro con Hanna es imperfecto, y, cuando el relato llega a la imagen de Hanna, Michael dice: "Sobre su rostro de entonces se han ido depositando en mi imaginación sus rostros ulteriores. Cuando la evoco tal como era entonces, la veo sin rostro. Tengo que reconstruírselo. Frente alta, pómulos altos, ojos azul pálido, labios gruesos y de contorno suave, sin arco en el labio superior, mentón enérgico. Un rostro ancho, áspero, de mujer adulta. Sé que me pareció hermosa. Pero no consigo evocar su hermosura" (p. 17).

Esta falibilidad de la memoria es recurrente en El lector. Algunos recuerdos de Michael son "borrosos" (p. 43). De algunos momentos Michael se acuerda "muy bien," pero de otros, de la misma época, no logra acordarse (p. 122). Muchos encuentros diferentes entre Hanna y Michael se funden en "un único y largo encuentro" (p. 44). Épocas recordadas como felices se revelan dolorosas bajo mayor inspección (p. 84). Luego de la muerte de su padre, hurgando en "el desván de [su] memoria en busca de los buenos momentos," Michael recupera una conversación que había olvidado (pp. 133-134). Algunas imágenes de Hanna le "han quedado": "Las tengo guardadas, puedo proyectarlas en una pantalla y contemplarlas, siempre invariables, sin señal de desgaste. A veces paso mucho tiempo sin traerlas a la mente. Pero siempre vuelven en algún momento, y entonces hay veces en que me veo forzado a proyectarlas y mirarlas repetidamente, una tras otra" (pp. 61-62).

La constatación de que la memoria es poco confiable no sorprenderá a ningún lector de la novela. ${ }^{3}$ No obstante, esta caracterización asume contornos de particular relevancia para la obra. Vimos el banco de imágenes que Michael dice guardar, intacto, de Hanna. Sin embargo, luego de haber presenciado el juicio, y de haber forjado visiones de los actos que le imputaban a Hanna, el recuerdo se contamina con las nuevas versiones imaginarias: "Sabía que

\footnotetext{
${ }^{3}$ No sorprenderá a ningún lector porque desconfiar de la memoria es un hecho notorio de la vida diaria, y además porque figura en incontables expresiones culturales. Para citar sólo un ejemplo, el personaje Quinn de la novela City of Glass de Paul Auster dice: "Pero eso era obra de la memoria, y él sabía que las cosas recordadas tenían la tendencia de trastornar lo que estuviera recordando. Como consecuencia, él nunca podía estar seguro de nada de eso" (But that was the work of memory, and remembered things, he knew, had a tendency to subvert the things remembered. As a consequence, he could never be sure of any of it) (The New York Trilogy. New York: Penguin Books [1990], p. 13).
} 
aquellas imágenes de la fantasía no eran más que miserables tópicos. No le hacían justicia a la Hanna que yo había conocido y estaba conociendo. Pero al mismo tiempo eran de una fuerza arrolladora. Destruían las imágenes que guardaba de Hanna en el recuerdo y se entreveraban con las imágenes de campos de exterminio que tenía en la mente" (p. 139).

Las imágenes que se hacen presentes aquí no deben menospreciarse. En el momento del juicio, Michael necesitó ir a un verdadero campo de concentración en busca de "aquellas imágenes que [le] faltaban" para darse una mejor idea de la vida de Hanna (p. 147). Por el contrario, en la actualidad la "carga visual" de los campos de exterminio es inmensa, como dice el narrador: "Hoy en día hay tantos libros y películas sobre el tema, que el mundo de los campos de exterminio forma ya parte del imaginario colectivo que complementa el mundo real. Nuestra fantasía está acostumbrada a internarse en él, y [...] no sólo se mueve en su interior, no se limita a percibir, sino que ha empezado a añadir y decorar por su cuenta" (p. 139). Por otra parte, el personaje principal del cuento "La circuncisión," en un momento en que es atacado por ser alemán, recuerda "las películas bélicas americanas y británicas que había visto de pequeño. Ya entonces sabía que era justo que los alemanes fueron los malos de la película, pero eso no evitaba que al verlas se sintiera de algún modo herido" (p. 187).

Retomaremos luego las implicaciones del último comentario, pero en este punto es importante subrayar la influencia que tienen las culturas visuales fabricadas sobre el acto mismo de percepción, y, claro, sobre el contenido de la memoria. Al problema de la desconfianza que se merece la memoria se suma ahora su miscegenación con visiones distorsionadas de los hechos, elevadas al estatus de tópicos. De hecho, lo que reúne Michael de su recorrido por el campo de Struthof no es enriquecedor: "Las impresiones que había recogido en Struthof se asociaban a las pocas imágenes que ya tenía de Auschwitz, Birkenau y Bergen-Belsen, y se fosilizaron junto a ellas" (p. 149). La singularidad de las vivencias de Michael en Struthof se pierde, hasta el punto de que su narración en este capítulo (2.15) se mezcla con los recuerdos de una visita posterior. La sedimentación generada por la carga visual estereotipada frustra la creación de nuevas memorias.

En todo caso, esta polinización de la memoria, efectuada por la percepción condicionada, no es unidireccional. En efecto, parte de la importancia de la memoria es el efecto que tiene sobre el presente. En un sentido importante,

4 "La circuncisión" forma parte de la colección de cuentos Amores en fuga, junto con "La niña de la lagartija," "El salto," "El otro," "Guisantes," "El hijo," y "La mujer de la gasolinera." 
ese efecto es emocional. "iPor qué me pongo triste cuando pienso en aquellos días?”, se pregunta Michael al recordar su relación con Hanna (p. 40). El contagio emocional que produce un recuerdo es conocido en la novela; encontramos otro ejemplo en la manera en que el joven Michael, antes de iniciar su relación, rebosaba de ansiedad con el solo acto de pensar en Hanna: "Pero lo cierto es que entonces, al pensar en lo que me había excitado tanto, volvía a excitarme" (p. 20).

El ciclo de interacciones entre presente y pasado se estrecha más. Esto sucede cuando observamos, como hace Michael, que el conocimiento posterior sobre ciertos hechos puede reconfigurar nuestra percepción sobre ellos, y hacernos así sentir en el presente, recordándolos, un sentimiento distinto al que en su momento habrían evocado. Michael lo expresa en una sencilla serie de preguntas: "¿Por qué lo que fue hermoso, cuando miramos atrás, se nos vuelve quebradizo al saber que ocultaba verdades amargas? ¿Por qué se oscurece el recuerdo de unos años felices de matrimonio cuando nos enteramos que el otro tuvo un amante durante todo ese tiempo? ¿Acaso porque en semejante situación no se puede ser feliz? Y, sin embargo, iéramos felices!” (p. 40). En el caso de la novela, Michael se siente triste al recordar a Hanna, a pesar de que el tiempo que pasó con ella fue feliz, porque el conocimiento posterior proyecta sobre los recuerdos un juego de sentimientos ajeno al original.

No obstante, este planteamiento amerita una reconsideración más minuciosa, que demuestra la tendencia de la memoria a remover los matices: ¿Michael habrá sido realmente feliz con Hanna? ¿Habrá olvidado al hacer un balance la frecuencia con la que debía capitular y aún reconocer "errores que no había cometido" y confesar "intenciones que nunca había albergado" (p. 51) con tal de conservarla a su lado? ¿Habrá tenido en cuenta las razones que pudieron haber llevado a una mujer mucho mayor a consentir en tener una relación acaparadora con un joven de quince años, tal vez por considerarlo débil y necesitado (v. pp. 110, 150)? ¿Habrá medido Michael el impacto atrofiante que tuvo esa relación sobre su carácter como pareja (v. pp. 199-200)?

Además, sobre el relato en general (nuestra única ventana hacia el mundo de Michael y Hanna) se extiende una desganada afirmación de veracidad que puede entenderse como un llamado adicional a la desconfianza. Hacia el final, el narrador dice: "La decisión de escribir nuestra historia la tomé poco después de su muerte. Desde entonces, esta historia se ha escrito muchas veces en mi cabeza, cada vez un poco diferente, cada vez con nuevas imágenes y fragmentos de acción y pensamiento. Por eso, además de la versión que he escrito, hay muchas otras. Supongo que esta versión es la verdadera, porque la he escrito 
mientras las otras se han quedado sin escribir. Esta versión pedía ser escrita; las otras no" (p. 202). El solo llamado a su redacción pretende distinguir la versión que hemos leído de las versiones que permanecieron alojadas en el pensamiento del narrador. Es una pretensión injustificada, pero nos alerta sobre el mecanismo falible en el que se convierte la memoria.

Vemos, entonces, un retrato de la memoria que la muestra imperfecta, maleable, nutriendo el presente y a la vez siendo reconfigurada por él. Si estos procesos afectan la memoria de un individuo que narra una experiencia que conoció de manera íntima, su efecto será incalculable sobre memorias más amplias, sobre memorias colectivas, sobre la historia. Michael, convertido luego en profesor de historia del derecho, comenta: "Ser historiador significa tender puentes entre el pasado y el presente, observar ambas orillas y tomar parte activa en ambas" (p. 170). ¿Será esta una admisión avergonzada de que ser historiador significa no tomar parte activa en ninguna orilla?

Esta problematización nos invita a preguntarnos si es posible que la autoconciencia de todo un país, de incontables individuos, esté mediada por los mismos problemas que exhibe la memoria en El lector. Por esta vía llegamos al siguiente tema.

\section{La culpa}

Otra idea resulta aún más importante que la memoria en los escritos de Schlink, y es la culpa. Para abordar este asunto, recordemos el cambio de registro que experimenta El lector. La primera parte de la novela se concentra en un encuentro romántico entre un joven y una mujer mayor. Unas páginas después, en la segunda parte, entra en escena un elemento político de gran carga moral: la acusación de que Hanna había sido agente del nazismo, y que había presidido sobre la muerte de decenas de mujeres durante su escape del campo de concentración.

Más arriba señalé que dilatar el ingreso del componente nazi es esencial para el efecto dramático de la obra. Imaginemos lo que le hubiera pasado al público si el orden de presentación hubiera sido otro. Por ejemplo, El lector pudo haber empezado con el juicio de Hanna como criminal de guerra, y, de este juicio, haber migrado hacia la adolescencia que el narrador pasó con ella. Si el autor hubiera optado por este orden, los lectores habríamos albergado una imagen de Hanna teñida irreparablemente por la imputación de que ella fue nazi. Los tópicos que desfiguraron los recuerdos de Michael habrían logrado un impacto semejante en nuestra percepción de los personajes. 
En cambio, casi la primera mitad de la novela transcurre en un ambiente de abandono y crecimiento en el cual no penetran los espectros del nazismo. Este orden de la narración nos permite un acercamiento a Hanna que en otras formas de narración sería inimaginable. En efecto, es difícil no tenerle aprecio a Hanna luego de verla trabajar largas horas, de presenciar su llanto frenético cuando Michael la deja sola en un hotel, de construir con él una relación tierna, intelectual, y erótica. Cuando ya hemos presenciado estas facetas de Hanna, nos enteramos de su pasado nazi. Uno de los retos para los lectores de la novela es decidir si este hallazgo es suficiente para reconfigurar nuestra impresión de ella, como vimos en la reflexión de Michael sobre la manera en que descubrir el adulterio de la pareja lleva a repensar la felicidad del matrimonio.

Nuestra reacción debe ser, por lo menos, ambigua, y Hanna no es el único personaje de Schlink frente al cual experimentamos esta vacilación. De hecho, el principal es Gerhard Selb, protagonista de la trilogía policíaca del mismo autor. Cuando iniciamos la primera de estas novelas (La justicia de Selb), encontramos a un detective de edad, viudo, reflexivo, coqueto, predecible en algunos gustos, intuitivo. Lo contrata su antiguo cuñado para investigar unos posibles delitos informáticos, y, luego de acompañarlo y acercarnos a él durante 137 páginas, Selb admite que fue "un nacionalsocialista convencido, miembro activo del Partido y un fiscal duro que también solicitó y obtuvo penas de muerte" (p. 137). Esta confesión es enteramente inusual para un público acostumbrado a oír rechazos al pasado nazi y muestras inequívocas de arrepentimiento. Además, los retos para nuestra tendencia a acoger a Selb no se detienen ahí, dado que las revelaciones de Selb sobre su nazismo son francas y abundantes. En La justicia de Selb, él recuerda "los uniformes verdes y grises de [su] mujer con el traje de las juventudes hitlerianas” (p. 238).

Conociendo que Selb fue un nazi convencido, una de las preguntas más recurrentes en la trilogía es por qué dejó de ser fiscal. En La justicia de Selb, el detective dice: "A mí me repugnó la actitud que mostraron mis colegas cuando fueron readmitidos y después, la ausencia de toda conciencia de la propia culpa. Bien, yo hubiera podido hacer que se me readmitiera con otra actitud y con la conciencia de la culpa. Pero de esa forma me hubiera sentido como un outsider y entonces preferí quedarme fuera a todos los efectos" (p. 272). En El fin de Selb, Selb continúa: "Yo ya no podía seguir siendo fiscal: primero, porque no se aceptaba a alguien con un pasado como el mío, y después, porque algo en mi interior se resistía a actuar, junto con los demás, como si careciéramos de pasado, aunque se nos instase a ello"' (p. 157). 
La reflexión más detallada sobre este punto la encontramos en El engaño de Selb: "He dado en el curso de mi vida muchas respuestas distintas a esta pregunta. Quizá todas sean correctas. Quizá no sea correcta ninguna. En 1945 no se me quiso porque había sido fiscal nazi, y cuando se quiso a los antiguos nazis de nuevo ya no quise yo. ¿Porque ya no era un antiguo nazi? ¿Porque me molestaba pensar en términos de 'corramos un velo' de aquellos que habían sido mis antiguos colegas en la judicatura y que hubieran sido los nuevos? ¿Porque no quería que nadie más me respondiera a la pregunta de qué era justo y qué injusto? ¿Porque soy mi propio jefe como detective privado? ¿Porque en la vida no debe acometerse otra vez aquello con lo que ya se ha acabado? ¿Porque no me gusta cómo huele la Administración?" (pp. 154-155).

En conjunto, vemos que Selb admite sin reservas que fue nazi en su juventud, y que la diferencia básica entre sus colegas y él es que ellos estaban dispuestos a olvidar y continuar. Selb no; a diferencia de los demás, él era profundamente consciente de su culpa. En efecto, él sabe que esto lo hace acreedor de sanciones: "Por los 'Heil Hitler!' de muchos años atrás," dice Selb en El fin de Selb, "y por los daños que causé entonces como fiscal... Tal vez por eso mereciera un castigo mayor" (p. 98).

Sin embargo, Selb se contrapone a una tendencia generalizada a intentar superar el pasado sin asumir la carga de la culpa. Entre los adherentes a esta tendencia, encontramos una variedad de reacciones. Una de ellas busca racionalizar los actos del pasado en función del deber. Así describe Selb a sus compañeros en la fiscalía: "Mis antiguos colegas de la administración de Justicia me habían enseñado que hacían falta dos cosas para superar el pasado: cinismo y el sentimiento de haber tenido razón en todo momento y de haber cumplido tan sólo con el propio deber" (La justicia de Selb, p. 300). La idea de cumplir el deber como una manera de superar el pasado surge también con el padre del protagonista del cuento "La niña de la lagartija." Según lo cuenta su viuda, para justificar los delitos cometidos siendo nazi este personaje "[c]opió artículos enteros del código penal. Los copió para demostrar que no podían castigarlo"' (Amores en fuga, p. 43). No obstante, esta apelación iuspositivista no es convincente: "Pero da escalofríos leerlo," continúa ella. "'Es como si lo reconociera todo pero se empeñara en que no había cometido ningún delito. Como si reconocieras que has envenenado a alguien, pero dejando claro que el plato estaba cocinado de acuerdo con el manual de la perfecta cocinera. Eso es lo que se siente al leerlo”' (p. 43).

Responder a las actuaciones reprochables apelando al deber, o, en concreto, a la aplicación ciega de las normas positivas, muestra ser un planteamiento 
insatisfactorio. Referido al castigo de los criminales de guerra nazis, este es un debate conocido dentro de la teoría jurídica, y Michael lo evoca en El lector así: "en el curso del seminario discutimos sobre el asunto de la prohibición de las penas retroactivas. La cuestión era: para condenar a los guardas y esbirros de los campos de exterminio, ibastaba con aplicar un artículo que estuviera recogido en el código penal en el momento de sus crímenes, o bien había que tener en cuenta el modo en que se entendía y aplicaba el artículo en el momento del juicio? ¿Qué pasaba si en aquella época esas personas no se consideraban afectadas por el artículo en cuestión?” (p. 86). La afirmación contenida en esta última pregunta es la que oímos del padre de "La circuncisión" y de los colegas de Selb en la trilogía; los personajes que hemos visto la consideran inaceptable.

Otra actitud frecuente en las obras de Schlink consiste en destruir para no perdonar ni reconciliarse con el pasado. Confrontado con el dilema de qué hacer con el cuadro, un objeto cargado de culpa y delito, el protagonista de "La niña de la lagartija" simplemente opta por quemarlo (Amores en fuga, pp. 47-48). Además, el mismo Selb recurre a esta salida cuando asesina a su antiguo cuñado, Korten, al verlo a punto de escapar impune de los crímenes del pasado, precisamente los crímenes que le habían allanado el camino para su éxito profesional en el presente. Sobre el asesinato de Korten, Selb comenta: "No le envidiaba su fama. Tampoco le perdonaba. Asesinar es no tener que perdonar" (La justicia de Selb, p. 314). Sobre el mismo punto, dice Selb: "Nunca he sentido remordimientos. A veces he pensado que tendría que sentirlos, porque no estuvo bien ni desde el punto de vista jurídico ni desde el punto de vista moral. Pero en mi alma no se instaló ese sentimiento. Tal vez la otra moral, la más antigua y más dura, la que precedió a la moral actual, sobrevive aún en nuestros corazones" (El fin de Selb, p. 206). Esta opción no acalla las objeciones morales a las acciones del pasado, ni constituye una solución adecuada para los problemas actuales.

Una respuesta adicional al peso del pasado es la de explicar las actuaciones de la época como reacciones propias del contexto; esto lleva a desecharlo como un problema moral sostenido, a olvidarlo. Welker, un heredero a quien Selb investiga por asesinato, dice: "Mire usted: a mí no me interesan las viejas historias. El Tercer Reich, la guerra, los judíos, los socios secretos, los herederos muertos, los antiguos derechos..., todo eso es agua pasada. Yo no tengo nada que ver con eso"” (El fin de Selb, p. 226). Los comerciantes se mantenían al margen de cualquier remordimiento sobre el nazismo, sobre lo cual Selb dice: "Era cierto cuando decían que ellos no habían sido nazis ni habían tenido nada en contra de los judíos, y que se habían mantenido en el terreno de la Constitución. Para ellos todo era sólo un terreno en el que estar y en el que 
poder agrandar sus empresas, hacerlas más ricas y poderosas" (El fin de Selb, p. 205). Korten, en el diálogo con Selb que desembocó en su asesinato, reafirma el olvido como la opción seguida por Alemania: "El hecho de que hayan sido olvidados los años entre 1933 y 1945 es el fundamento sobre el que se ha construido nuestro Estado"' (La justicia de Selb, p. 304).

El mundo, sin embargo, no ha permitido que Alemania olvide su pasado con la facilidad que proponen las citas anteriores. Sarah, la novia de Andi en "La Circuncisión," le explica a Andi por qué lo asocian con el Holocausto: "Tú qué tienes que ver con el Holocausto, ¿no? Muy sencillo: eres alemán, eso es lo que tienes que ver con el Holocausto. Y eso a la gente le incomoda, aunque sean demasiado educados para demostrártelo" (Amores en fuga, p. 208).

El continuo señalamiento de los alemanes como culpables con frecuencia genera resentimiento y agotamiento, reacciones que vimos en las respuestas de algunos de los personajes citados. Por ejemplo, ya observamos, en el cuento "La circuncisión," que si bien Andi admite que los alemanes deberían ser los malos de las películas, afirma que esto, de todas maneras, lo hiere. En parte, el agotamiento y frustración de los alemanes por su pasado se debe a que no es fácil reaccionar ante la realidad de un mal tan notorio. Por ejemplo, icuál es la reacción de Michael ante la presencia irrefutable del mal en el que participó Hanna? Aturdimiento (p. 97), embrutecimiento (p. 112), anestesia (p. 158). El mismo Schlink, tomando prestada la expresión de Hannah Arendt, se refiere a la "banalidad del mal" ocurrido bajo el nazismo, una expresión que comunica la sorprendente irreflexión de los crímenes nacional-socialistas.

Por su parte, Andi, en "La circuncisión," presenta una larga defensa de la angustia que le causa el ser constantemente incriminado por el pasado alemán: "'iEs justo que la gente que nació muchos años después de la guerra, y que nunca le ha hecho daño a nadie, tenga que aguantar que le recuerden y le echen en cara

\footnotetext{
${ }^{5}$ Schlink (en la nota al pie 68 de su artículo, publicado en esta edición de Precedente) se refiere al libro de Hannah Arendt en general. Encontramos una descripción de la idea de la banalidad del mal en el post scriptum de ese libro: "No, Eichmann no era estúpido. Únicamente la pura y simple irreflexión —que en modo alguno podemos equiparar a la estupidez— fue lo que le predispuso a convertirse en el mayor criminal de su tiempo. Y si bien esto merece ser clasificado como 'banalidad', e incluso puede parecer cómico, y ni siquiera con la mejor voluntad cabe atribuir a Eichman diabólica profundidad, también es cierto que tampoco podemos decir que sea algo normal o común" (Eichmann en Jerusalén. Trad. Carlos Ribalta. Barcelona: Lumen [1999], p. 418).
} 
cada dos por tres el pasado singular del lugar donde vive? [...] Mira, es cierto que es necesario recordar el pasado para que no se repita, y también por respeto a las víctimas y a sus descendientes; pero el Holocausto y la guerra son cosas de hace cincuenta años, y no pueden cargárseles a los nietos las culpas que haya contraído la generación de los padres y los hijos. La gente de Dachau, cuando va al extranjero, se avergüenza de su lugar de origen, y hay chavales que se hacen neonazis porque están hartos de que se remueva el pasado constantemente. No me parece que todo eso sea tan simple”" (Amores en fuga, pp. 196-197).

Sobre este soliloquio de Andi caben por lo menos dos observaciones. En primer lugar, vemos surgir con toda claridad el problema de heredar las culpas de las generaciones anteriores, un dilema al cual Schlink, nacido en 1944, se habrá enfrentado con frecuencia. Veremos más adelante una de sus manifestaciones en El lector, pero otra de ellas es evidente en Amores en fuga: al protagonista de "La niña de la lagartija" lo preocupa el hecho de tener en su poder un cuadro obtenido mediante la conducta criminal de su padre. Debate consigo mismo qué hacer con él: "¿Debía vender el cuadro y disfrutar del dinero? ¿O hacer una buena obra? Al aprovecharse de las injusticias cometidas por su padre, ino había contraído una deuda con las víctimas?" (Amores en fuga, p. 45). Esta última pregunta expone el cimiento que puede producir lazos de culpa entre generaciones sucesivas: ise beneficia la generación actual de las culpas de la generación previa? Si la respuesta es afirmativa, desde esta óptica podría sugerirse que es moralmente legítimo considerar culpables a las generaciones que se habrían estimado impolutas. La pregunta es relevante en una variedad de entornos, como en el debate sobre las llamadas reparations que los descendientes de esclavos en los Estados Unidos le están cobrando a la administración, o como en la discusión sobre la culpa de las actuales generaciones europeas frente a la suerte del continente africano.

La segunda observación que debemos hacer sobre el discurso de Andi es el peligro de aumentar indefinidamente el alcance de la incriminación. Andi señala que la asfixia producida por esta inculpación ha llevado a mucha gente joven a adoptar el nazismo. Después de todo, si soy inherentemente culpable de algo, hasta el punto de que hacerlo o no hacerlo me representarán sanciones iguales, iqué me impide salir a cometerlo? Esta es, en efecto, una reflexión de Michael en El lector. Meditando sobre su regreso a la casa de Hanna, después de haberla sorprendido desvistiéndose, Michael se pregunta cómo obtuvo el valor para hacerlo: "¿Quizá la educación moralizante se revolvía de algún modo contra sí misma? Si la mirada concupiscente era por sí misma tan mala como la satisfacción del deseo, y la fantasía activa tanto como el hecho en sí mismo, ipor qué negarse a la satisfacción y al hecho?" (p. 22). 
Esta tentación se agrava al tener en cuenta lo impronunciable, y hasta impensable, que fue el nazismo para la Alemania de la posguerra. Selb muestra esto de forma contundente cuando, en un momento de la narración, compara a dos jóvenes policías con agentes de la Waffen-SS, y dice: "Esto es, por supuesto, una comparación inadmisible, porque en la actualidad tenemos un orden liberal y democrático, pero la mezcla de celo, seriedad, inseguridad y servilismo en los rostros es la misma" (La justicia de Selb, p. 197). Vemos aquí la vacilación de quien ha sido entrenado para abjurar, hasta en lo más esencial, el nazismo. Las circunstancias lo invitan a hacer una comparación, pero se restringe llamándola inadmisible, y reforzando casi ritualmente el orden político ahora existente; sin embargo, ante la fuerza de la semejanza, termina por defenderla.

Esta exclusión del pasado nazi es uno de los temas principales de Schlink en el artículo publicado en esta edición de Precedente: "el período de 1933 a 1945 no se puede borrar de la historia de Alemania," dice Schlink hacia el final. Y continúa: "La labor [de integrar el período de 1933 a 1945 en la historia alemana] consiste en admitir y soportar el mal en su banalidad, y asimismo en reconocer la banalidad de sus expresiones intelectuales. Al entenderlo así se integrará en la historia. Si esto se hace con éxito, Schmitt regresará a las filas de los académicos constitucionales y de los teóricos de la política de su época. Entonces la Goethe House y la New School no organizarán una conferencia sobre Schmitt el individuo, sino sobre los problemas que él y muchos otros trataron y que él ni creó ni solucionó. Entonces se le negará el carácter de clásico que sus defensores intentan asegurarle." En otras palabras, el ostracismo radical que se ha buscado para el nazismo en Alemania ha ungido a Carl Schmitt con un aura tal de misterio y magia que le ha reportado un reconocimiento inmerecido. Por lo tanto, no es sólo la violencia de los jóvenes en las calles, sino las distorsiones en las universidades, algunos efectos de la actitud que busca desterrar el pasado, en lugar de confrontar la culpabilidad con aplomo.

En esta sección hemos visto, entonces, que una de las virtudes dramáticas de El lector es permitirnos percibir a Hanna antes de que pueda ser desfigurada por nuestro conocimiento de su pasado. Encontramos en Gerhard Selb otro personaje sometido al mismo trato, produciendo una reacción igualmente ambigua. Vimos diversas actitudes frente al pasado en las obras de Schlink: superarlo mediante la racionalización, destruirlo, o justificarlo y olvidarlo. En todas estas reacciones subyace un conflicto sobre la culpa que puede producir agotamiento y frustración, o incluso generar las conductas que se imputan. A este ya problemático retrato debemos añadirle las dificultades que vimos al 
repasar el rol de la memoria en El lector. Recordar no es un asunto sencillo, guiado por procesos transparentes; todo lo contrario, es un acto imperfecto, que entremezcla pasado, presente, y fantasía. En consecuencia, no es fácil juzgar cómo deben los alemanes (y en general cualquier persona en presencia de un pasado lleno de culpas) recordar su propio pasado, especialmente cuando el mal es de tal magnitud que dificulta el hecho mismo de comprenderlo. Tampoco es fácil decidir cómo debe el mundo recordar y acoger a los alemanes (y, de nuevo, en general a cualquier persona con un pasado culpable): ino son Selb y Hanna personajes que en el universo de Schlink nos ofrecen un modelo para hacerlo, obligando a los lectores a verlos como personas antes de verlos como nazis? Las reflexiones que provocan los textos de Schlink, y que se construyen con situaciones y personas cautivantes, nos ayudan a darles matices a los problemas que los prejuicios y los sentimientos pueden llegar a mutilar.

Cierro esta sección con tres observaciones adicionales, sobre la culpa dentro de las organizaciones, sobre la posible culpa de los aliados, y finalmente sobre la exculpación y la mentira vital.

En primer lugar, la tarea de determinar la culpa de una nación es un ejemplo en mayor escala de un problema práctico y cotidiano dentro del derecho: ¿cómo determinar la culpa dentro de las organizaciones? Algunos sistemas no conciben la responsabilidad penal de las personas jurídicas, mientras otros sí lo hacen. En ambos casos, uno de los principales problemas que enfrenta un proceso que involucre organizaciones es hallar a los responsables. ${ }^{6}$

La justicia de Selb incluye una discusión brillante de este reto. Nägelsbach, un policía amigo de Selb, comenta lo difícil que es precisar la culpa dentro de una organización. Se imagina así la manera en que la compañía RCW ejecutó el asesinato de Peter Mischkey: "La RCW está contrariada con Mischkey, y la situación es cada vez más incómoda, y entonces algún responsable dice:

\footnotetext{
${ }^{6}$ El derecho comercial ha diseñado figuras que facilitan determinar cuándo se entiende que una sociedad ha dado su consentimiento. Un ejemplo de estas figuras es la llamada representación aparente o presunta del último inciso del artículo 640 del Código de Comercio colombiano: "ARTICULO 640. Cuando el suscriptor de un título obre como representante, mandatario u otra calidad similar, deberá acreditarla.

La representación para suscribir por otro un título-valor podrá conferirse mediante poder general o poder especial, que conste por escrito.

No obstante, quien haya dado lugar, con hechos positivos o con omisiones graves, a que se crea, conforme a los usos del comercio, que un tercero está autorizado para suscribir títulos en su nombre, no podrá oponer la excepción de falta de representación en el suscriptor."
} 
"Bien, ya basta", y su subordinado se lleva un susto y por su parte transmite esto: "Preocúpese de que Mischkey nos deje en paz, aguce el ingenio", y el que recibe este mensaje quiere mostrar su eficiencia y aguijonea a sus subordinados y les estimula para que se les ocurra algo, que puede ser tranquilamente algo extraordinario, y al final de esta larga serie hay uno que piensa que lo que de él se exige es que mate a Mischkey" (pp. 207-208). El resultado: no fueron los poderosos directamente, sino un subordinado "megalómano," quien llevó a cabo el crimen (p. 220). Es necesario ser consciente de la dificultad que representa precisar a los funcionarios responsables de cierta conducta organizacional, especialmente cuando es posible que la transmisión capilar de deseos dentro de la organización no involucre órdenes explícitas. No estamos lejos de extenderle esta dificultad a la escala nacional, donde las decisiones de los líderes no necesariamente requieren pronunciamientos incriminantes. Se hace, pues, más compleja la caracterización de los líderes y de la organización como responsables.

La segunda observación con la que cerraré esta sección estudia la posible culpa de los aliados. El "bombardeo" se presenta con cierta frecuencia en la obra de Schlink, pero libre de reflexiones o dudas. Por ejemplo, Selb perdió a sus padres durante el bombardeo (El fin de Selb, p. 81), y también murieron así los abuelos paternos del protagonista de "La niña de la lagartija" (Amores en fuga, p. 37). Los bombardeos, claro, fueron aquellos adelantados por los aliados contra Alemania, muchos de estos ataques de una crueldad especial cuando la lógica militar lo hacía innecesario. ${ }^{7}$ Otro ejemplo impactante de la manera en que los aliados no figuran en la ecuación de la culpa es este: el punto nunca interrogado en el relato de Hanna es el hecho de que la iglesia estalló en llamas por una bomba de los aliados. La acusación consiste en culpar a las guardianas por no abrir la puerta de la iglesia, y en este cuestionamiento nunca se menciona la circunstancia, brutal pero evidente, de que los aliados provocaron la situación bombardeando una iglesia. Sobre los aliados pesa un completo silencio; encontramos alguna dosis de rechazo a la presencia militar norteamericana en Alemania en El engaño de Selb, pero esto no se traduce en mayores elaboraciones. Es posible que esto responda a un veto implícito, compartido por los personajes de Schlink y producto de la manera en que se desarrolló la guerra, contra apuntar hacia los aliados como culpables de cualquier cosa. Esto nos invita a destacar la forma en que lo permitido dentro del discurso tiene una fuerte incidencia sobre la identificación de los culpables.

${ }^{7}$ Sobre este punto, ver: W. G. Sebald, Sobre la historia natural de la destrucción. Trad. Miguel Sáenz. Barcelona: Anagrama (2003). 
El silencio sobre la culpa de los aliados nos lleva a la tercera y última observación de esta sección. En El lector presenciamos un esfuerzo casi sistemático, casi concertado, por exculparse. Las acusadas, por ejemplo, buscan constantemente reducir su culpabilidad señalando a Hanna como la verdadera responsable de la muerte de las mujeres en la iglesia. A su vez, la gente del pueblo, que presenció pasivamente la incineración, busca realzar elementos que justifiquen esa pasividad, con el fin de ser exonerados: los testigos del pueblo "tenían razones para andarse con cuidado, no fuera a ser que les acusasen también a ellos de no haber hecho nada para salvar a las prisioneras" (p. 108). Cuando ellos ven la oportunidad de señalar a Hanna como líder, acogiendo lo que plantean las demás acusadas, lo hacen: "la existencia de una cabecilla representaba una coartada perfecta para los habitantes del pueblo: para ayudar a las prisioneras habrían tenido que plantar cara a un disciplinado comando a las órdenes de un superior, y no a un puñado de mujeres desconcertadas" (p. 128).

Por su parte, el mismo Michael Berg entra en un tortuoso debate consigo mismo sobre la culpa que debería sentir frente a Hanna. Durante años, Michael había cargado con la culpa de haber traicionado a Hanna: él percibía la desaparición de Hanna de su vida como el resultado de una actitud suya, en exceso pasiva, en su último encuentro. Esto lleva a una fértil serie de reflexiones en la que Michael intenta exonerarse del sentimiento de traición, con el argumento de que ella había cometido el mal mayor e imperdonable de ser una criminal de guerra; pero esto enfrenta a Michael con su propio contraargumento, nuevamente repleto de culpa, de que él se había enamorado de una criminal de guerra. Michael busca paz donde también nosotros querremos encontrarla: él conoció a Hanna sin saber de su pasado. Así lo explica Michael: "Era a [Hanna] a quien tenía que señalar con el dedo. Pero, al hacerlo, el dedo acusador se volvía contra mí. Yo la había querido. No sólo la había querido, sino que la había escogido. Me replicaba a mí mismo que en el momento de escoger a Hanna no sabía nada de su pasado. Y así intentaba refugiarme en esa inocencia con la que los hijos aman a los padres" (p. 160).

\footnotetext{
${ }^{8}$ Incluyo otras dos citas pertinentes: "de nuevo me rebelaba contra aquella sensación, y la acusaba a ella, y me parecía pobre y tosco el truco con que se escabullía de su culpa. Dejarse pedir cuentas sólo por lo muertos, reducir la culpabilidad y el arrepentimiento a un problema de insomnio y pesadillas... iY los vivos qué? Pero en realidad no estaba pensando en los vivos, sino en mí mismo. ¿Acaso yo no podía pedirle cuentas también? ¿Qué había hecho ella de mí?" (p. 188). La segunda es esta: "En los primeros tiempos después de la muerte de Hanna siguió atormentándome la duda de si realmente la había negado y traicionado, de si al amarla me hice culpable, de si debería haberme liberado de ella de palabra y de obra, y de cómo podría haberlo hecho. A veces me preguntaba si era responsable de su muerte. Y a veces me enfurecía con ella y por todo lo que me hizo. Hasta que el odio perdió fuelle y las dudas trascendencia. No importa lo que hice o no hice, ni lo que ella me hizo a mí: es mi vida, eso es todo" (p. 202).
} 
Confrontando a Hanna en el juicio, Michael se encuentra dividido: "Quería comprender y al mismo tiempo condenar el crimen de Hanna. Pero su crimen era demasiado terrible. Cuando intentaba comprenderlo, tenía la sensación de no estar condenándolo como se merecía. Cuando lo condenaba como se merecía, no quedaba espacio para la comprensión. Pero al mismo tiempo quería comprender a Hanna; no comprenderla significaba volver a traicionarla. No conseguí resolver el dilema. Quería tener sitio en mi interior para ambas cosas: la comprensión y la condena. Pero las dos cosas al mismo tiempo no podían ser" (p. 148). Dentro de este ambiente ambiguo, es evidente que Michael no busca, como los demás personajes que hemos visto, deshacerse de la culpa descargándola sobre otro.

Sin embargo, para Michael el esfuerzo es más difícil, y con frecuencia termina siendo un nuevo portador del sentimiento que evita. Él reconoce su situación singular en la siguiente observación: "No me consolaba pensar que mi sufrimiento por haber amado a Hanna fuera de algún modo el paradigma de lo que le pasaba a mi generación, de lo que les pasaba a los alemanes, con la diferencia de que en mi caso resultaba más difícil hurtar el bulto o enmascarar el fondo de la cuestión" (pp. 161-162).

Michael asocia su rechazo de Hanna con la actitud de los demás miembros de su generación. En efecto, las generaciones más jóvenes también entran en la lógica de la exoneración al dirigir su ataque contra las generaciones previas, como una forma de no considerarse culpables. En esta discusión reaparecen los problemas de transmisión de la culpa que habíamos visto en otras obras de Schlink, y en particular en el discurso de Andi. Michael se pregunta lo siguiente sobre su generación: "icómo debía interpretar mi generación, la de los nacidos más tarde, la información que recibíamos sobre los horrores del exterminio de los judíos? [...] iEs ése nuestro destino: enmudecer presa del espanto, la vergüenza y la culpabilidad? ¿Con qué fin? [...] [M] e pregunto si las cosas debían ser así: unos pocos condenados y castigados, y nosotros, la generación siguiente, enmudecida por el espanto, la vergüenza y la culpabilidad" (p. 99).

Este silencio, al que el pasado somete a su generación, lleva a Michael más adelante a pensar sobre la culpa colectiva: "La culpabilidad colectiva, se le acepte o no desde el punto de vista moral y jurídico, fue de hecho una realidad para mi generación de estudiantes. [...] Señalar a otros con el dedo no nos eximía de nuestra vergüenza. Pero sí la hacía más soportable, ya que permitía transformar el sufrimiento pasivo en descargas de energía, acción y agresividad. Y el enfrentamiento con la generación de los culpables estaba preñado de energía” (p. 159). 
La única excepción a esta tendencia es Hanna. Aparentemente con el fin de ocultar su analfabetismo, ella permite que la reconozcan como autora de un reporte que la inculpa de manera especial. Esto se traduce en una condena excepcional.

La actitud de Hanna se inscribe dentro de lo que Selb, en la trilogía, postula como la "mentira vital." "La gente no asesina sin más por dinero," dice Selb. "Asesina exclusivamente por un motivo: porque no puede salvar de otro modo una vida basada en la mentira. El asesinato por celos: cuando la amante esté muerta ya es mía y nadie puede quitármela, ni el otro ni ella misma. [...] Existe el asesinato colectivo por causa de vidas basadas en mentiras colectivas; la historia de este siglo está llena de ellos. Es verdad que también existe el asesinato por codicia. Pero su objetivo no es arrebatar y acumular dinero. También éste tiene que salvar sueños de grandeza e importancia" (El engaño de Selb, p. 225). El psiquiatra Eberlein intenta corregir este planteamiento de Selb, diciéndole que existen "ideas esenciales para la vida" (El engaño de Selb, p. 240), pero unas páginas más adelante Selb insiste, buscando la mentira vital de un amigo suyo (p. 287).

La mentira vital es, pues, aquella ficción que estructura algunas vidas, y que lleva a unos cuantos a hacer cualquier cosa con tal de preservarla. Selb se interroga a sí mismo varias veces en la trilogía por su propia mentira vital, la que lo llevó a asesinar a Korten. Si bien Selb no se responde la pregunta, a la luz de las páginas anteriores es posible conjeturar que su mentira consiste en la idea de que la gente debería sentirse culpable por sus malas actuaciones, y en ciertos casos ser castigada. Este postulado encuentra obstáculos en ciertas decisiones de Selb en El engaño de Selb, pero el sentido de justicia que termina por hospitalizar a Selb es un buen indicio de su mentira vital. Tal vez busque, al implantar justicia, librarse de su propia conciencia de haber cometido injusticias.

Volviendo a Hanna, nos debemos preguntar cuál es su mentira vital. En cierto momento de la novela, Michael, súbitamente, cae en cuenta de que Hanna es analfabeta, y esto le permite explicar muchas anomalías en la conducta de Hanna, y aún en decisiones de ella como la de entrar a la SS en vez de aceptar una promoción en Siemens (donde sus limitaciones serían expuestas) (p. 123). Michael pone así en perspectiva la agotadora vida de Hanna: ella "[n]o sólo luchaba en el juicio. Luchaba siempre, y había luchado siempre, no para mostrar a los demás de lo que era capaz, sino para ocultarles de qué no era capaz. Una vida cuyos avances eran enérgicas retiradas y cuyas victorias eran derrotas encubiertas" (p. 125). 
Hanna no estaba dispuesta a exponerse como analfabeta para salvarse de la condena, y Michael contempla hacerlo por ella, pero se abstiene. "Para ella," concluye Michael, "su imagen valía esos años de cárcel" (p. 129). Las reflexiones de Michael sobre esta decisión introducen en El lector la idea selbiana de la mentira vital: "iDe qué le servía esa imagen falsa, que la amordazaba, la paralizaba, le impedía desarrollarse como persona? Con la energía que invertía en sostener la mentira de su vida, podría perfectamente haber aprendido a leer y a escribir" (p. 129) (énfasis fuera del texto). La idea resurge más adelante: "¿Tenía derecho a privarla de la mentira de su vida sin ofrecerle a cambio una alternativa de futuro?” (p. 135). Y hace así su última aparición explícita: "Tenía que luchar por que se hiciera justicia, dejando aparte la mentira vital de Hanna, es decir, que se hiciera justicia independientemente de que ello le conviniese a Hanna o no" (p. 150).

Si Hanna estaba dispuesta a irse a la cárcel para preservar el secreto sobre su analfabetismo, debemos preguntarnos qué asociaba con esa condición, y también debemos tener en cuenta que en la cárcel ella efectivamente aprendió a leer y escribir. Hanna no era analfabeta porque despreciaba lo escrito; por el contrario, ella había buscado lectores, tanto en las jóvenes de los campos de exterminio, como en Michael durante la posguerra. Una persona analfabeta en una sociedad fruto de la Ilustración enfrenta obstáculos insolubles, no sólo en su sentido diario de orientación, sino en su contacto con otras personas y con el pasado. No poder leer en una sociedad letrada implica, en cierto modo, estar condenado al presente, con destellos del pasado que sólo existirán gracias a la memoria propia. Hanna buscaba, entonces, formar parte de esa sociedad del libro, y no quería ser vista como una criatura del pasado remoto, como una menor de edad. Es así como Michael se explica la situación de Hanna: "El analfabetismo es una especie de minoría de edad eterna. Al tener el coraje de aprender a leer y escribir, Hanna había dado el paso que llevaba de la minoría a la mayoría de edad, un paso hacia la conciencia" (p. 176). Su mentira vital puede ser, entonces, estimar que ella de hecho formaba parte de la sociedad moderna de la cultura y el conocimiento; había mantenido vigente su mentira a través de lectores sucesivos que le permitían hacerse partícipe a pesar de sus limitaciones. Ante la posibilidad de admitir su exclusión, Hanna prefiere someterse a la cárcel, donde se asegura su propia entrada a ese mundo volviéndose alfabeta. La decisión que toma Hanna al enterarse de su libertad puede ser el resultado de la conciencia de que el mundo en que ella creía participar, ahora que lo conoce por medio del contacto directo con las letras, siempre había sido una creación fantástica. Tal vez lo hizo para no enfrentar, exonerada y en condiciones de igualdad, al mundo que debió sufrir las malas actuaciones con las que Hanna buscó preservar su mentira vital. 


\section{Conclusión}

La mejor razón para acercarse a El lector es que es, simplemente, un buen libro. Logra una fina combinación de indagación psicológica y filosófica, por un lado, con erotismo e intriga, por otro. Muchas de las imágenes del libro, como su textura, son sencillas, pero dan la sensación de contener un valiente análisis de la existencia y las emociones.

Habiendo hecho esa recomendación general, propongo brevemente una manera en que El lector puede contribuir al pensamiento jurídico en Colombia. Debemos recordar, en este contexto, que El lector no es una novela de un aficionado del derecho, sino de un muy comprometido practicante: Schlink es juez en Berlín, y además profesor universitario en esta disciplina; Schlink ha escrito docenas de artículos especializados, y algunos libros, sobre temas jurídicos.

Muchos problemas propios del derecho encuentran un vocero en los personajes de Schlink. Entre otros, encontramos sofisticadas discusiones sobre la libertad de empresa, sobre la responsabilidad de las organizaciones, sobre la culpa colectiva, sobre la culpa intergeneracional. Sin embargo, El lector puede hacer un aporte que se torna más urgente en Colombia: las reflexiones derivadas de esta novela muestran la dimensión del problema que enfrentará la sociedad colombiana ante el escenario de justicia transicional que se está gestando. Una vez se hayan desmovilizado los alzados en armas, icuál será la reacción de la sociedad? ¿Racionalización basada en normas positivas y deberes (órdenes legítimas, delitos políticos)? ¿Estupefacción ante el mal perpetrado, olvido pleno, justificaciones basadas en las exigencias coyunturales? ¿Se absolverán las generaciones posteriores, y los herederos de quienes se beneficiaron de la violencia, de las posibles deudas contraídas con las poblaciones remotas y las gruesas de familias desplazadas? Y en el debate tampoco podemos olvidar el lugar de las víctimas que presenciarán estos procesos, ni el de las personas que intentarán forjar vidas normales con las personas que se sometan a los procesos de reincorporación a la vida civil. El lector pone al descubierto estos problemas, contribuyendo así a una posible labor de sensibilización.

\section{Obras citadas de Bernhard Schlink}

Bernhard Schlink y Walter Popp, La justicia de Selb. Trad. Ángel Repáraz. Barcelona: Anagrama (2003).

Bernhard Schlink, El engaño de Selb. Trad. Ángel Repáraz. Barcelona: Anagrama (2004).

Bernhard Schlink, El fin de Selb. Trad. Txaro Santoro. Barcelona: Anagrama (2005).

Bernhard Schlink, Amores en fuga. Trad. Joan Parra Contreras. Barcelona: Anagrama (2002). 
